\title{
Extraction and Estimation of Chlorophyll from Medicinal Plants
}

\author{
Rajalakshmi .K ${ }^{1}$, N. Banu ${ }^{2}$ \\ ${ }^{1}$ Research Scholar, Department of Biotechnology, Vels Institute of Science, Technology and Advanced Studies, Chennai, Tamil Nadu, India \\ ${ }^{2}$ Associate Professor, Department of Biotechnology, Vels Institute of Science, \\ Technology and Advanced Studies, Chennai, Tamil Nadu, India.
}

\begin{abstract}
Chlorophyll is a green pigment, which is structurally similar to porphyrin pigments such as heme and it is produced through the same metabolic pathway. Chlorophyll benefits the body in a unique and distinctive ways. It is helps to cleanse harmful toxins from the body and it is also uses to fight infection. A recommended and regular intake of chlorophyll can keep the circulatory and digestive systems much healthier. In the present study, the chlorophyll was extracted from the leaves from nine medicinal plants and characterized by UV-Visible spectroscopy. Concentration of chlorophyll a and b was calculated using Arnon method. Chlorophyll content was higher in Mimosa pudica than other medicinal plants which are used in this study.
\end{abstract}

Keywords: Chlorophyll a, chlorophyll b, Medicinal plants, UV- Visible spectroscopy, Mimosa pudica.

\section{Introduction}

Chlorophyll is a green pigment consists of tetrapyrrole ring with a central magnesium ion. It has a long hydrophobic phytol chain in its structure. It is found in some varieties in plants and algae (Aminot, 2000). Two types of chlorophyll, $a$ and $b$ are present in green algae and terrestrial plants. The difference between these two chlorophylls is a methyl moiety in chlorophyll $a$ replaced by a formyl group in chlorophyll $b$. The ratio of chlorophyll $a$ to chlorophyll $b$ in higher plants is approximately 3:1. Chlorophyll absorbs light mainly in the red $(650-700 \mathrm{~nm})$ and the blue - violet $(400-$ $500 \mathrm{~nm})$ regions of the visible spectrum. Green light ( $\sim 550$ $\mathrm{nm}$ ) is not absorbed but reflected giving chlorophyll its characteristic color. Chlorophyll $a$ possesses a green-blue color, and chlorophyll $b$ possesses a green-yellow color (Arnon, 1849).

In tumor or cancer therapy chlorophyll or chlorophyll derivatives can be utilized as a photodynamic agent. (Brandis et al., 2006). It can be studied, modified and synthesized in chemistry and physics disciplines for different applications, that is electronic, photophysics, optoelectronic, electrochemistry (Nurhayati and Veinardi Suendo, 2011). Chlorophyll fluorescence parameters and evaluation of chlorophyll content and relationships between chlorophyll $\mathrm{a}$ and $\mathrm{b}$ were determined in Dezful olive trees (khaleghi,et al, 2012). José Francisco (2008) estimated the chlorophyll concentration in leaves of tropical wood species from Amazonian forest using portable chlorophyll meter. Non-destructive optical methods have been developed for estimation and measurement of chlorophyll concentrations in leaves. It express relative values of chlorophyll rather than absolute values per or leaf mass unit of area, but the concentration of chlorophyll present in the leaves are proportional to the values obtained through this methods with portable chlorophyll meters. (Richardson et al. 2002). Kousar et al., (2007) extracted estimated and determined chlorophyll and different pigment in black gram leaves using different methods, the main pigments are chlorophyll a, b and pheophytin. It was studied at different wave lengths. A simple and easy incubation method grinding and centrifugation procedures were described among few methods. The recovery of chlorophyll pigments by incubation method in which tender leaf tissue in $80 \%$ buffered acetone at $4{ }^{\circ} \mathrm{C}$ give higher yield of pigments compared to other methods.

\section{Materials and Methods}

\section{Collection of plants}

The medicinal plants include Melothira maderaspatana (mumusukkai keerai) Clitoria ternatea (Sagupushpam) Boerhavia diffusa (Mukkarattai keerai) Pongamia pinnata(L.) Pierre (Punga maram) Aegle marmelos.(L.) correa (Vilvam) Phyllathus fraternus (Kizanelli) Mimosa pudica (Touch me not) Pisonia grandis (Lecchai Kottai keerai) Acalypha indica (Kupameni) was collected from MSME, herbal garden in Guindy, Chennai, India.

\section{Extraction of chlorophyll (Arnon, 1949)}

One gram of finely cut fresh leaves were taken and ground with $20-40 \mathrm{ml}$ of $80 \%$ acetone. It was then centrifuged at $5000-10000 \mathrm{rpm}$ for $5 \mathrm{mins}$. The supernatant was transferred and the procedure was repeated till the residue becomes colorless. The absorbance of the solution was red at $645 \mathrm{~nm}$ and $663 \mathrm{~nm}$ against the solvent (acetone) blank.

\section{Estimation of Chlorophyll content}

The concentrations of chlorophyll a, chlorophyll b and total chlorophyll were calculated using the following equation:

Total Chlorophyll: $20.2\left(\mathrm{~A}_{645}\right)+8.02\left(\mathrm{~A}_{663}\right)$

Chlorophyll a: $12.7\left(\mathrm{~A}_{663}\right)-2.69\left(\mathrm{~A}_{645}\right)$

Chlorophyll b: $22.9\left(\mathrm{~A}_{645}\right)-4.68\left(\mathrm{~A}_{663}\right)$

\section{Results and Discussion}

Greens are important sources of protective food which are highly beneficial for the maintenance of good health and prevention of diseases. In this study commonly available plant leaves were used to estimate the chlorophyll content. A total of ten plants were selected for this study these include 


\section{International Journal of Science and Research (IJSR) \\ ISSN (Online): 2319-7064}

Index Copernicus Value (2013): 6.14 | Impact Factor (2014): 5.611

Melothira maderaspatana (mumusukkai keerai) Clitoria ternatea (Sagupushpam) Boerhavia diffusa (Mukkarattai keerai) Pongamia pinnata(L.) Pierre (Punga maram) Aegle marmelos. (L.) correa (Vilvam) Phyllathus fraternus
(Kizanelli) Mimosa pudica (Touch me not) Pisonia grandis (Lecchai Kottai keerai) Acalypha indica (Kupameni).

Table 1: Estimation of Chlorophyll in Medicinal plants

\begin{tabular}{|c|c|c|c|c|}
\hline S. No & Plant Name & $\begin{array}{c}\text { Chl a } \\
(\boldsymbol{\mu g} / \mathbf{m l})\end{array}$ & $\begin{array}{c}\text { Chl b } \\
(\boldsymbol{\mu g} / \mathbf{m l})\end{array}$ & $\begin{array}{c}\text { Total Chl } \\
(\boldsymbol{\mu g} / \mathbf{m l})\end{array}$ \\
\hline 1 & Melothira maderaspatana & 27.8 & 31.8 & 59.6 \\
\hline 2 & Clitoria ternatea & 27.6 & 35.6 & 63.2 \\
\hline 3 & Boerhavia diffusa & 27.5 & 33 & 60.5 \\
\hline 4 & Pongamia pinnata(L.) pierre & 34.3 & 36.8 & 71.1 \\
\hline 5 & Aegle marmelos. $($ L. $)$ correa & 31.8 & 35.6 & 67.4 \\
\hline 6 & Phyllathus fraternus & 33 & 33 & 66 \\
\hline 7 & Mimosa pudica & 39.4 & 43.2 & 82.6 \\
\hline 8 & Pisonia grandis & 30.5 & 35.6 & 66.1 \\
\hline 9 & Acalypha indica & 35.6 & 34.3 & 69.9 \\
\hline
\end{tabular}

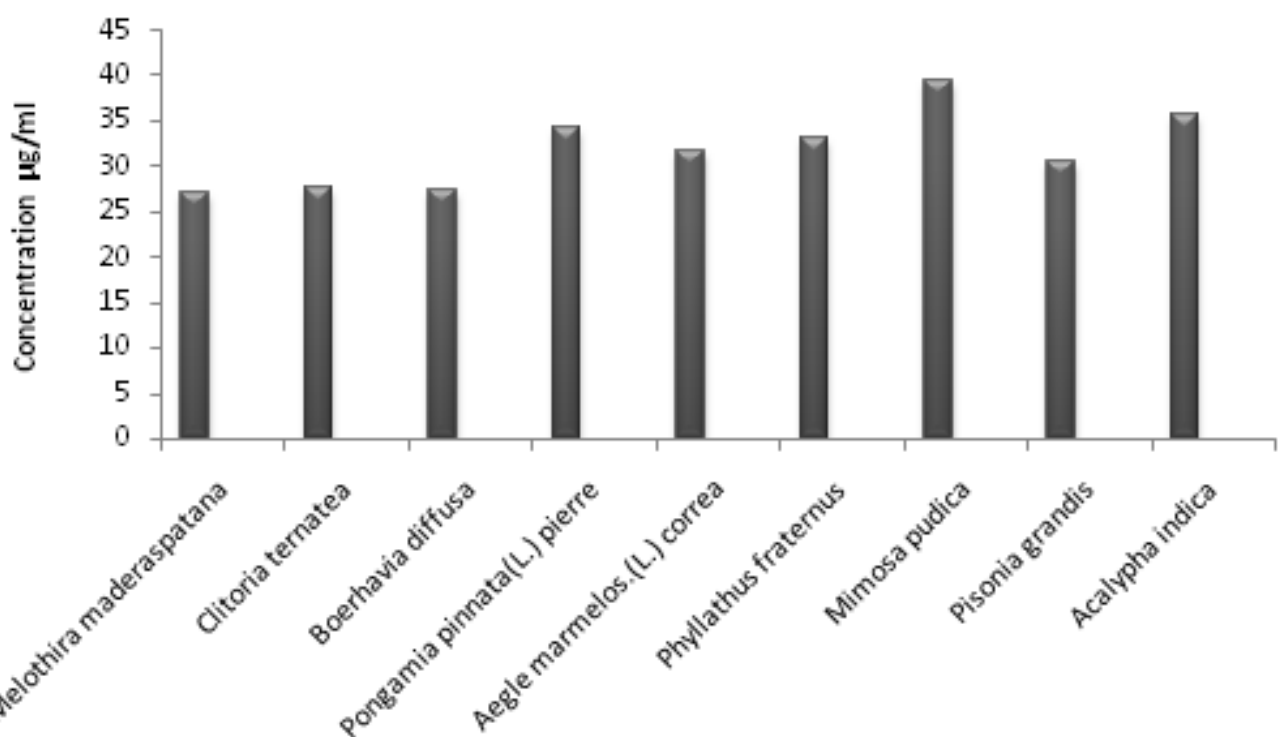

Figure 1: Concentration of chlorophyll a.

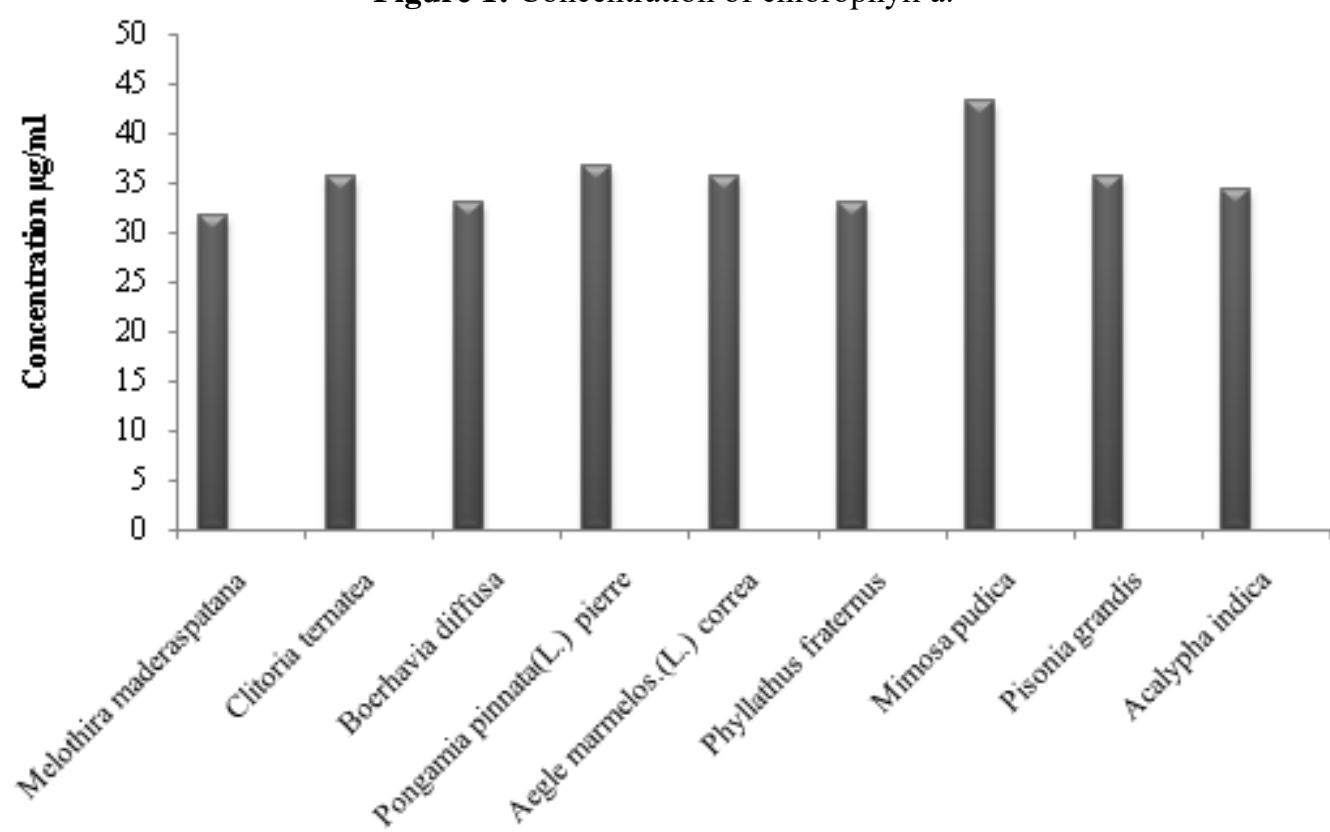

Figure 2: Concentration of chlorophyll b. 


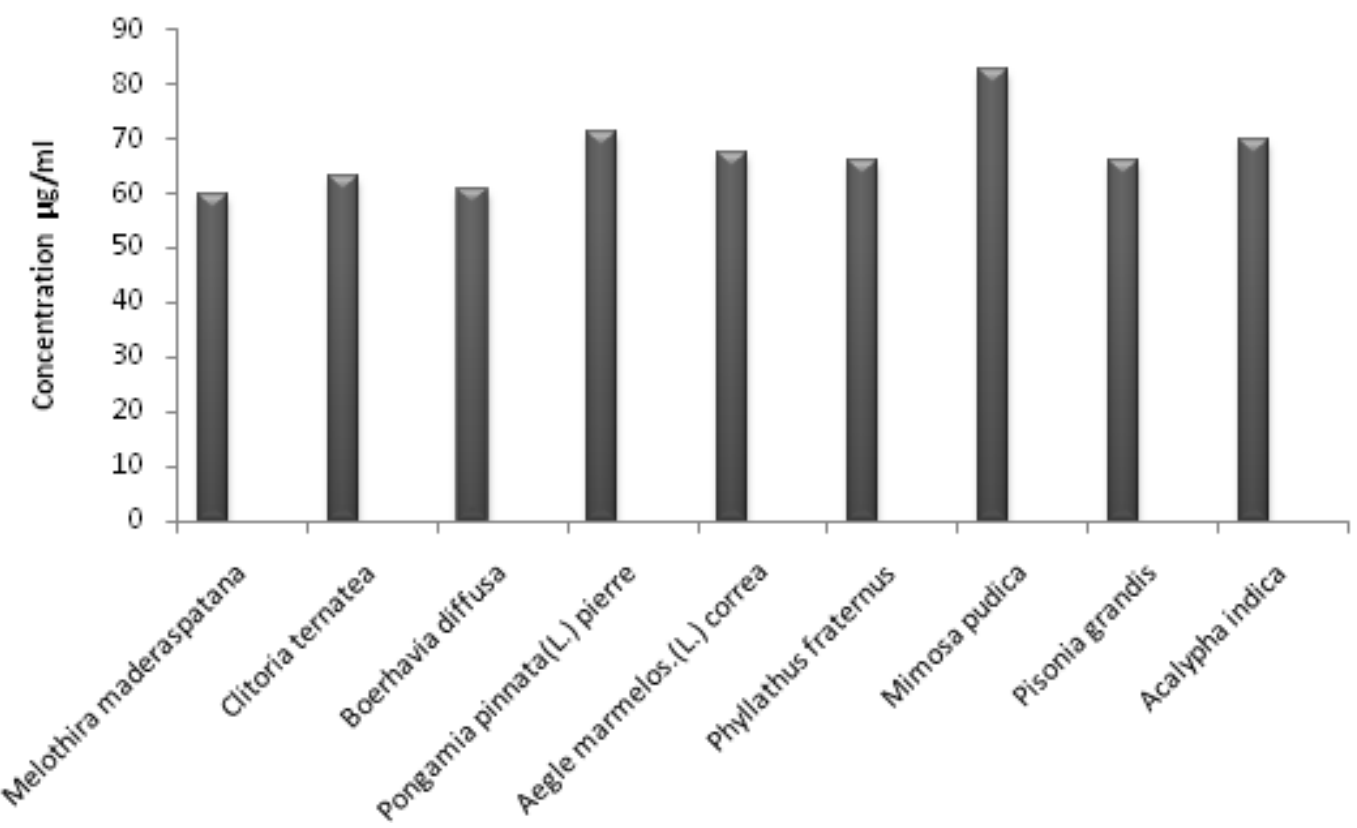

Figure 3: Concentration of chlorophyll Total Chlorophyll

Chlorophyll estimation was done in the fresh green leaf samples extracted with the acetone solvent the absorbancy readings of chlorophyll extracts were measured in two different wavelengths $645 \mathrm{~nm}$ and $663 \mathrm{~nm}$ respectively. Based on the absorbancy value calculations were made using Arnon's (1949) equation and the amount of chlorophyll a, chlorophyll $\mathrm{b}$ and total chlorophyll were estimated and tabulated. The highest total chlorophyll content $(a+b)$ was detected in Mimosa pudica $(82.6 \mu \mathrm{g} / \mathrm{ml})$, followed by Pongamia pinnata (L.) pierre $(71.1 \mu \mathrm{g} / \mathrm{ml})$ Acalypha indica $(69.91 \mu \mathrm{g} / \mathrm{ml})$. Khaleghi (2012) showed that amount of leaf chlorophyll a and total chlorophyll $(\mathrm{chl} \mathrm{a}+\mathrm{b})$ were reduced by increasing water deficit and the amount of total chlorophyll and chlorophyll a were higher in plants were received $100 \%$ ET crop than 65 and $45 \%$ ET crop.

José Francisco et al., (2008) determined Chlorophyll Concentrations in tropical tree species by portable Chlorophyll meter with appropriate adjustment equations. Portable Chlorophyll meter provides convenient and nondestructive way to estimate the Chlorophyll concentrations. Faisal and Anis et al., 2006 reported higher amount of chlorophyll a $(0.91 \pm 0.19 \mathrm{mg} / \mathrm{g} \mathrm{FW})$ and chlorophyll b $(0.61 \pm 0.09 \mathrm{mg} / \mathrm{g} \mathrm{FW})$ in micro propagated plants of Psoralea corylifolia compared to chlorophyll a $(0.83 \pm 0.31$ $\mathrm{mg} / \mathrm{g} \mathrm{FW})$ and chlorophyll b $(0.53 \pm 0.14 \mathrm{mg} / \mathrm{g} \mathrm{FW})$ in seedlings. Sukran Dere (1998) was found that the level of chlorophyll a in fresh water form cladophora glomerata was rather high in comparison with Ulva rigita L., Codium tomentosum and Cladostephus verticillatus Ag. The chlorophyll a level was also found higher in Ulva rigit. In earlier studies, it was suggested that in all algae groups almost the chlorophyll a relating to the pigment level was same. The amount of chlorophyll a and chlorophyll b in normal leaf was less when compared to the regenerated leaf. Indira Priyadarsini et al., 2015 estimated the chlorophyll content of Tridax procumbens grown in normal and polluted region and reported that the chlorophyll content in normal and polluted regions is $2.99 \mathrm{mg} / \mathrm{g}$ and $2.56 \mathrm{mg} / \mathrm{g}$ respectively.

\section{Conclusion}

Chlorophyll from Melothira maderaspatana (mumusukkai keerai) Clitoria ternatea (Sagupushpam) Boerhavia diffusa (Mukkarattai keerai) Pongamia pinnata(L.) Pierre (Punga maram) Aegle marmelos.(L.) correa (Vilvam) Phyllathus fraternus (Kizanelli) Mimosa pudica (Touch me not) Pisonia grandis (Lecchai Kottai keerai) Acalypha indica (Kupameni) was extracted and estimated. Considering the results obtained in this work, among these nine medicinal plants chlorophyll content in Mimosa pudica leaves was higher followed by Pongamia pinnata (L.) pierre $(71.1 \mu \mathrm{g} / \mathrm{ml}) \quad$ Acalypha indica $\quad(69.91 \mu \mathrm{g} / \mathrm{ml})$. The concentration of chlorophyll may vary in different region.

\section{References}

[1] Aminot A and Rey F. March 2000. Standard procedure for the determination of chlorophyll $a$ by spectroscopic methods. International Council for the Exploration of the Sea. ISSN 0903-2606.

[2] Aron D, 1949. Copper enzymes isolated chloroplasts, polyphenoloxidase in Beta vulgaris. Plant Physiology. 24: $1-15$.

[3] Brandis, A. S., Y. Salomon, and A. Scherz, 2006. Chlorophyll Sensitizers in Photodynamic Therapy, Advances in Photosynthesis and Respiration, 25, 461483.

[4] Faisal M and M Anis. (2006). Thidiazuron induced high frequency axillary shoot multiplication in Psoralea corylifolia. Biol Plantarum. 50:437-440.

[5] H. Scheer, 2006, In Chlorophylls and Bacteriochlorophylls, B. Grimm, R. Porra, W. Rudigger, H. Scheer Eds., Springer, Dordrecht p. 1.

[6] Indira P, Shamshad AS and PM John. (2015). The effect of air pollution on some biochemical factors of some plant species growing in Hyderabad. Int. J. Pharm. Bio. Sci. 6:1349 - 1359.

[7] José Francisco de Carvalho Gonçalves, Ulysses Moreira dos Santos Junior e Emerson Alves da Silva, 2008. 


\section{International Journal of Science and Research (IJSR) \\ ISSN (Online): 2319-7064}

Index Copernicus Value (2013): 6.14 | Impact Factor (2014): 5.611

Evaluation of a portable chlorophyll meter to estimate chlorophyll concentrations in leaves of tropical wood species from Amazonian forest. Hoehnea 35(2): 185188.

[8] Khaleghi. E, Arzani. K, Moallemi.N, Barzegar.M, 2012. Evalution of chlorophyll content and chlorophyll Fluorescence parameters and Relationships between chlorophylla, b and chlorophyll content Index under water stress in Olea europaea cv. Dezful, World Academy of science, Engineering and Technology 68 1154-1157.

[9] Kousar M., Suresh Babu. G., Lavanya. GR, Abraham G. 2007. Studies of Chlorophyll by different methods in Black gram (Vigna mungo). International Journal of Agricultural Research. 2:651-654.

[10] Młodzińska E (2009). Survey of Plant Pigments: Molecular and Environmental Determinants of Plant Colors. Acta Biologica Cracoviensia Series Botanica 51/1: 7-16.

[11] Nurhayati and Veinardi Suendo, 2011. Isolation of Chlorophyll $a$ from Spinach Leaves and Modification of Center Ion with Zn2+: Study on its Optical Stability. Jurnal Matematika \& Sains, Vol. 16 Nomor 2.

[12] Pelletier, P.J. and Caventow, J.B., 1818. Notice sur la matiere verte des feuilles (chlorophylls), Ann. Chem. Phys., 8, 194.

[13] Richardson, A.D., Duigan, S.P. \& Berlyn, G.P. 2002. An evaluation of noninvasive methods to estimate foliar chlorophyll content. New Phytologist 153: 185-194.

[14] Schertz, F. M. 1928. The extraction and separation of chlorophyll $(a+b)$, carotin and xanthophyll in fresh green leaves, preliminary to their quantitative determination. Plant Physiol. 3: 211-216.

[15] Sukran Dere., Tohit Gunes., Ridvan Sivaci. 1998. Spectrophotometric Determination of Chlorophyll - A, $\mathrm{B}$ and Total Carotenoid Contents of Some Algae Species Using Different Solvents. Tr. J. of Botany 22 13-17.

[16] Ulatowska-Jarza, A., U. Bindig, H. Podbielska, I. Holowacz, W. Strek, G. Muller, and H. J. Eichler, 2005. Spectroscopic Properties of a Chlorophyll-Based photosensitive Dye Entrapped in Sol-Gel Fibre-Optic Applicators, Mater. Sci.-Poland, 23, 111- 122. 